\title{
Cracow Clean Fossil Fuels and Energy Efficiency Program Progress Report
}

\author{
prepared by \\ Brookhaven National Laboratory \\ and \\ Biuro Rozwoju Krakowa S.A.
}

October 1998

\author{
Prepared for: \\ Office of Fossil Energy \\ U.S. Department of Energy \\ Under Contract No. DE-AC02-98CH10886
}




\section{DISCLAIMER}

This report was prepared as an account of work sponsored by an agency of the United States Government. Neither the United States Government nor any agency thereof, nor any of their employees, nor any of their contractors, subcontractors, or their employees makes any warranty, express or implied, or assumes any legal liability or responsibility for the accuracy, completeness, or usefulness of any information, apparatus, product or process disclosed, or represents that its use would not infringe privately owned rights. Reference herein to any specific commercial product, process, or service by trade name, trademark manufacturer, or otherwise, does not necessarily constitute or imply its endorsement, recommendation, or favoring by the United States Government or any agency thereof. The views and opinions of authors expressed herein do not necessarily state or reflect those of the United States Government or any agency, contractor, or subcontractor thereof. 


\section{Table of Contents}

\section{INTRODUCTION}

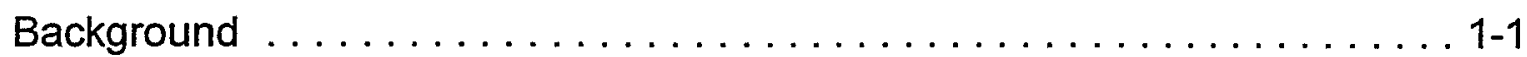

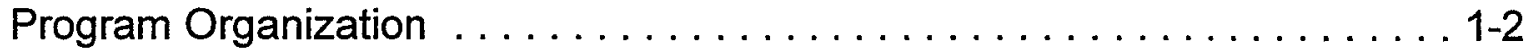

2. SUMMARY OF PHASE I STUDIES

Home Stoves . . . . . . . . . . . . . . . . . . . . . . . . . . . 2-1

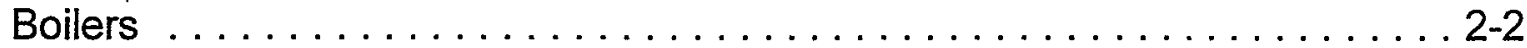

Energy Conservation Demonstration . . . . . . . . . . . . . . . . 2-6

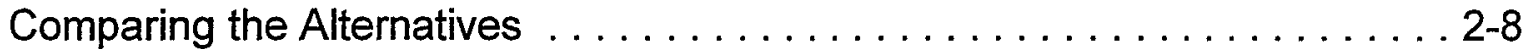

3. PHASE III SUCCESS STORIES

Control Techtronics International, Inc. . . . . . . . . . . . . . . . . 3-1

Honeywell ............................... 3-5

Shooshanian Engineering Associates, Inc. . . . . . . . . . . . . . 3-7

LSR Technologies, Inc. . . . . . . . . . . . . . . . . . . . . . 3-9

4. TRENDS IN CRACOW

Reconstruction and Modernization of the District Heating System . . . . . 4-1

Gaining New Customers by MPEC and ECK . . . . . . . . . . . . . 4-2

Availability of Energy Carriers $\ldots \ldots \ldots \ldots \ldots \ldots \ldots \ldots \ldots \ldots \ldots, 2$

Energy Conservation Activities $\ldots \ldots \ldots \ldots \ldots \ldots \ldots \ldots \ldots \ldots .44 .2$

Changes in Environmental Protection Regulations . . . . . . . . . . . 4-3

Low Emission Sources . . . . . . . . . . . . . . . . . . . . 4-3

Capital Availability . . . . . . . . . . . . . . . . . . .

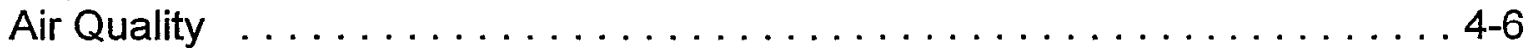

5. WORK IN PROGRESS

Comprehensive Plan for Low Emission Sources . . . . . . . . . . . . . . 5-1

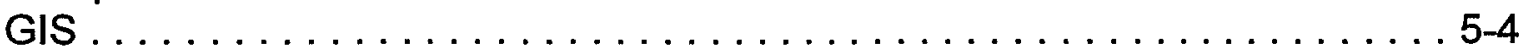

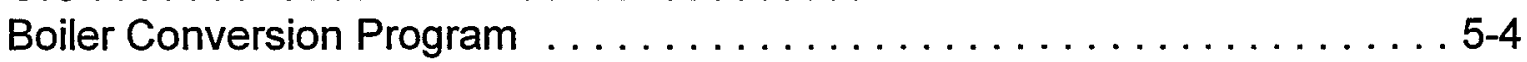

References 


\section{List of Figures}

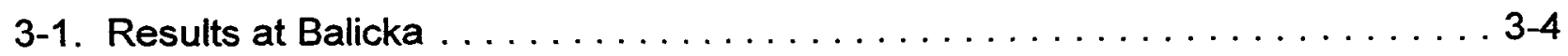

3-2. Simple Illustration of the LSR Core Separator System . . . . . . . . 3-10

3-3. Typical Core Separator Arrangement . . . . . . . . . . . . . . . . . .

3-4. Trend in Installed Capacity of Core Separators in Poland . . . . . . . . . 3-12

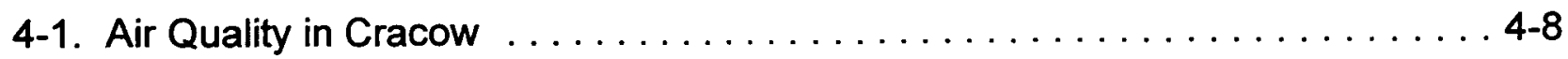

\section{List of Tables}

3-1. LSR Core Separators Produced by Ecolnstal $\ldots \ldots \ldots \ldots \ldots \ldots . . \ldots$ 3-14

4-1. Solid-fuel-fired Boilers in Cracow $\ldots \ldots \ldots \ldots \ldots \ldots \ldots \ldots \ldots \ldots \ldots .4$

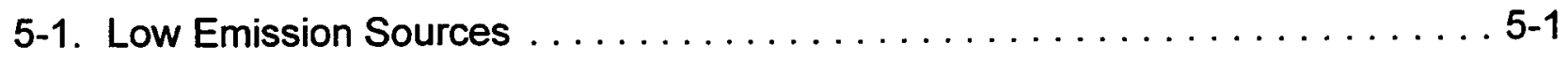

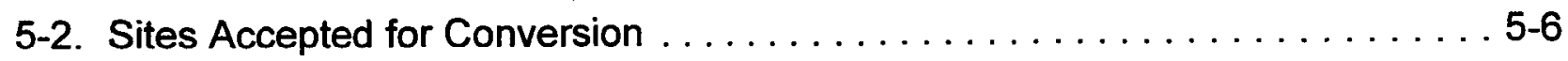


Since 1990 the U.S. Department of Energy has been involved in a program aimed at reducing air pollution caused by small, coal-fired sources in Poland. The program focuses on the city of Cracow and is designed so that results will be applicable and extendable to the entire region. This report serves both as a review of the progress which has been made to date in achieving the program objectives and a summary of work still in progress.

\section{Background}

Cracow is one of the largest and oldest cities in Poland. It is situated in the south of the country on the banks of the Vistula River. From the 11th until the 17th centuries, it was the capital of Poland. Today, Cracow is a city of 750,000 residents, one of the largest centers of higher education in Poland, an important industrial center, and is of particular importance because of the number and kinds of historic buildings and sites. For this reason, Cracow was included by the UNESCO in the list of the world's cultural heritages.

For about three decades, significant air pollution has been one of Cracow's most serious problems. Because the city is situated in the Vistula River valley, it is poorly ventilated and experiences a high concentration of air pollutants. The quality of air in Cracow is affected mainly by industry (Sendzimir Steelworks, energy industry, chemical plants), influx from the Silesian industrial region (power plants, metallurgy), transboundary pollution (Ostrava Czech Republic), and local sources of low pollution, i.e. more than 1,000 boiler houses using solid fuels and more than 100,000 coal-fired home stoves (in 1990). These local sources, with low stacks and almost no pollution-control equipment, are responsible for about $35-40 \%$ of the air pollution; they cause the highest concentration of air pollutants within the historic center of Cracow. As a group they are called the Low Emission Sources (LES).

A 1991 inventory of the Low Emissions Sources in Cracow recorded 1,344 boiler houses, including 1,134 using solid fuel, with a total design output of $964.7 \mathrm{MW}$. There also were 100,000 coal-fired home stoves and an additional 17,000 rooms heated by small, individual boilers using solid fuel. The boiler houses consumed approximately 375,000 $\mathrm{Mg}$ of solid fuels annually; the home stoves and small individual boilers used an additional $100,000 \mathrm{Mg}$. The boilers and stoves used $230,000 \mathrm{Mg}$ of coal fines, $88,000 \mathrm{Mg}$ of coke, and $157,000 \mathrm{Mg}$ of coal at that time.

The air pollution problem has had a significant effect on accelerated deterioration of historic buildings, as well as on the health of residents (respiratory tract disorders) and the condition of green areas and soil. During the 1987 heating season in Cracow, the average ambient particulate concentration was over $100 \mu \mathrm{g} / \mathrm{m}^{3}$ - more than twice the standard. During the same year ambient $\mathrm{SO}_{2}$ concentrations exceeded the standard by a factor of three [1]. 
With the political changes at the end of the 1980's environmental activism grew. Many informal, local environmental organizations formed. This growing environmental concern fed into the formation of Poland's 1991 National Environmental Policy [2].

The formal basis for the U.S. assistance to Poland in this area was provided by the Support for Eastern European Democracy (SEED) Act of 1989. Part of this legislation directed the U.S. Department of Energy (USDOE) to cooperate with U.S. and Polish experts to undertake an assessment program in Poland to use fossil fuels cleanly in smallscale combustion equipment. This program became specifically directed toward the emissions problems of low emissions sources in Cracow and a total budget of 20 million dollars was allocated.

\section{Program Organization}

Funding for this program has been provided to DOE by the U.S. Agency for International Development (USAID). In 1991, USAID and USDOE signed an interagency agreement to conduct the project. Representatives from both organizations worked with Polish officials to establish an eight-member Bilateral Steering Committee (BSC) to plan and oversee the Program. In 1991, U.S. and Polish officials signed a Memorandum of Understanding formally initiating and directing the Cracow Clean Fossil Fuels and Energy Efficiency Program.

Developing a program approach for the most effective use of the available funds required considerable effort on the part of all project participants. The team recognized early that the cost of solving the low emissions problem even in only one city far exceeded the amount of available U.S. funds. Economic conditions in Poland limited availability of local capital funds for environmental projects. Imposing environmental costs on struggling companies or city residents under the difficult conditions of the early 1990's required careful consideration of the economic and political impacts. For all of these reasons the program sought to identify technologies for achieving air quality goals which, through improved efficiency and/or reduced fuel cost, could be so attractive economically as to lead to self-sustaining activities beyond the end of the formal project.

The effort under this program has been focused into 5 main areas of interest as follows:

1) Energy Conservation and Extension of Central Station District Heating. Conserving energy and installing energy-efficiency measures reduce the load and emissions from boiler houses or make more heat available for expanding the district heating system. Extending the central station district heating system would eliminate local boiler houses in favor of heat supplied by more efficient, less-polluting co-generation plants.

2) Replacement of Coal- and Coke-Fired Boilers with Natural Gas-Fired Boilers.

3) Replacement of Coal-Fired Home Stoves with Electric Heating Appliances.

4) Reduction of Emissions from Stoker-Fired Boiler Houses. Many local boiler houses are relatively new or are far from existing district heating lines. These boiler houses will not 
be replaced or eliminated, but there are numerous alternatives to increase their efficiency and reduce their emissions.

5) Reduction of Emissions from Coal-Fired Home Heating Stoves. Due to economic considerations, it is likely that many coal-fired home heating stoves will remain for some time. Therefore, this Program also explored ways to reduce emissions from existing stoves.

In addition the BSC defined three major phases for the work. Phase I consisted of information gathering and analysis of technical alternatives. In this phase various technological alternatives for pollution reduction were identified. Combustion tests were performed to measure the emissions reduction performance of each technology, and economic analyses were performed to determine the cost of implementing these alternatives. Regulatory and financial incentives were identified to encourage the implementation of these technological alternatives. Phase I was conducted cooperatively by numerous organizations, under DOE direction including: Biuro Rozwoju Krakowa (BRK), Brookhaven National Laboratory, Pacific Northwest National Laboratory, Electrotek Concepts, Inc., Cracow Polytechnic University, and the Academy of Mining and Metallurgy. Phase I studies including an energy conservation demonstration, air quality impact studies, public opinion studies, source test results, and option analyses are all described in the Phase I report [3].

Phase 2 consisted of three public meetings designed to inform U.S. and Polish businesses about the program and its opportunities. The meetings were held in Chicago, Illinois and Washington, D.C. in June 1992 and in Cracow in November, 1992.

Phase III consists primarily of projects conducted cooperatively by U.S. and Polish companies to introduce U.S. technologies and services to reduce emissions in Cracow. Projects were selected through a solicitation issued by the U.S. DOE in September, 1992. The solicitation requested proposals from U.S. firms for cost-shared Cooperative Agreements. U.S. firms that proposed were strongly encouraged to include Polish firms as team members. The minimum cost sharing was $50 \%$ to be provided by the U.S. firm, its Polish team members, or third party investors.

All proposals to the solicitation were required to describe a project to provide equipment, fuels, or services to reduce pollution from low emission sources in the city of Cracow within the scope of one of the five areas of interest. The equipment, fuels, or services proposed were to be associated with a U.S. technology that was either commercially available or ready for commercialization. The proposed projects were to be of two to four years in duration and were to establish businesses in Poland to market and utilize the proposed technologies for the immediate benefit of Cracow. Once established by the projects, these businesses were to remain and to service the large markets in Poland and elsewhere in Eastern and Central Europe.

Proposals were received by USDOE in February 1993. The submitted proposals were evaluated by a USDOE board according to predetermined criteria that were published along with the original solicitation document. These criteria were used to score each 
proposal according to the performance and advantages of the proposed technology, the size of the market and the proposer's approach to it, projected pollution reductions and associated costs, and the capabilities and experience of the proposed U.S.-Polish teams. The USDOE evaluation board was advised by a group of Polish engineers and the BSC.

Following the evaluation process a total of nine firms were selected for awards of Cooperative Agreements in the Cracow Program. The scope of work for each of these projects has been described earlier $[4,5]$. Some of the projects terminated before completing the full planned scope for various reasons. This progress report describes the achievements which have been realized to date by work under Phase III of the program. This will be followed by a final report after all program work has been completed.

In parallel with the Phase III Cooperative Agreement projects, the BSC has commissioned some additional work to be done in Cracow. Generally this work addresses needs of the City of Cracow in planning for the long term changes in energy use and also addresses some aspects of the LES problem for which no Phase III proposals were received. This work includes: development of an updated source database, preparation of an energy plan for specific city districts, economic and incentives studies, information dissemination, and assistance in the conversion of hand-fired boilers in the central part of the City. 


\subsection{Summary of Phase I Studies}

In Phase I, the low emissions sources were evaluated to determine their contribution to Cracow's emissions and to identify ways to eliminate or reduce their emissions. Testing characterized the low sources in terms of their efficiencies, fuels, and emissions.

Several possibilities were identified for eliminating or reducing emissions from the low-stack sources in Cracow. These include connecting boilers to the existing district heating network, converting some boilers to gas, modernizing boiler houses, converting home stoves to gas or electricity, and using improved fuels. The technical analyses evaluated the feasibility of these options and developed costs for their implementation.

Finally, legal and economic analyses helped identify incentives that the local government could offer to encourage the implementation of effective options to reduce emissions.

This chapter highlights selected results of Phase 1 . The reader is referred to Reference 3 for detailed descriptions and results from each of the Phase I activities.

\section{Home Stoves}

At the start of the Program there were about 100,000 coal-fired home stoves in Cracow. In addition, there are an estimated 7 million home stoves in Poland. These are traditional storage stoves, built of brick and covered with ornate ceramic tiles. The stoves are generally fired once or twice a day during the heating season. Each firing period lasts about $11 / 2$ hours, during which the stove's mass is heated. After the burning period, the room is heated as the masonry slowly cools. As part of Phase I, a stove was installed for testing at the laboratory of the Academy of Mining and Metallurgy (AGH) in Cracow.

The stove was tested with several different coals, briquettes, and coke, and with different operating procedures. Test results showed efficiencies between 47 and $68 \%$, with the upper values indicating proper operational procedures, and the lower ones representing poor operational procedures with major faults. An average efficiency for the population of stoves in the city is $55 \%$, much higher than commonly believed. The strongest adverse effect on the efficiency is prolonged time of combustion, caused by closing the stove door too late; this reduces efficiency to 47 to $49 \%$. Introducing improved operating procedures developed during this program would increase efficiency to between 73 and $75 \%$.

Low-volatiles-content fuels - briquettes and coke - have the best environmental performance. With briquettes, performance strongly depends upon operating procedure, and the improved operating procedure sharply reduces overall emissions. With a higher volatiles-content fuel, emissions performance is much less dependent upon the operating procedure. Generally, fuels with the highest volatiles content produce the highest emissions during the initial, devolatilization stage of combustion, and changes in operating procedures which affect the later stages of combustion have little effect on overall emissions. However, with low volatile fuels the emission rates are more uniform over the entire combustion period, and changes made during the later stages of combustion can affect total emissions during the firing cycle. 
The stoves are significant contributors to Cracow's pollution. Although consuming much less fuel than the boilers, stoves produce as much or more seasonal particulate emissions. This is exacerbated by the use of cheaper coals.

Coal-fired tile stoves can be eliminated by installing electric heating elements in existing stoves (to be used as storage heaters) or by replacing stoves with gas-fired central heating. A public opinion survey administered during Phase I showed that many residents would like to convert their stoves to gas or electric heating; electric heating is preferred. A number of stoves have in fact been converted, indicating a willingness on the part of Cracow residents to pay for the convenience of electric versus coal heating. The main obstacle to more widespread adoption of this conversion is the lack of transformer stations and power distribution networks.

Converting a stove to electric heating costs about US $\$ 1,000$ [1995], which includes costs for building wiring upgrades and distribution system improvements. In the center of Cracow and adjacent areas, the electricity supply is sufficient to allow conversions. For the city as a whole, the distribution system can meet only a part of the potential demand. Gas conversions are more expensive. The city could offer financial assistance to residents who want to implement these conversions; the utility company may also require assistance.

Due to technical and economic constraints, all of Cracow's stoves will not be converted or eliminated in the near future. The use of alternative fuels could provide an interim solution; test results showed that the use of briquettes could reduce particulate emissions 12 to 15 times the current rates. Unfortunately, the availability of briquettes is currently very limited. The city could encourage the market for briquettes or other high quality fuels by restricting the use of lower quality fuels. At the same time, residents could be made aware of the operating procedure developed during Phase I which reduces both fuel use and emissions.

\section{Boilers}

Before the start of this Program, the Cracow Voivodeship (Province) Department of Environmental Protection commissioned the Cracow Development Office (BRK) to conduct an inventory of Cracow boiler houses. The inventory was done in the fourth quarter of 1990 and the first quarter of 1991.

In total, 1,344 boiler houses were registered, with total capacity of 1,050.4 MW. These boiler houses have 2,920 boilers installed, of which $77.5 \%(2,262)$ are solid-fuel-fired. Solid fuelfired boilers include:

- 229 stoker-fired boilers with mechanical grates (511 MW)

- 2,033 fixed grate boilers (452 MW), including:

1,118 coke-fired boilers

685 coke/coal mix-fired boilers

230 coal-fired boilers. 
A significant majority ( 185 or $80.5 \%$ ) of the boilers with mechanical grates have air pollution control devices, mostly cyclones or multicyclones. Only 94 fixed-grate boilers (4.6\%) have pollution control devices.

Fixed-grate boilers are either cast-iron, designed to burn coke, or steel, designed for coal. They can also be fired with a coal-coke mixture of various proportions. Boiler houses in the center of Cracow are generally fixed-grate, and their output generally does not exceed $1 \mathrm{MW}$.

Stoker-fired boilers are designed to use hard coal fines (size 5 to $10 \mathrm{~mm}$ ). These are located primarily at the outskirts of Cracow and supply heat to a larger group of buildings. Their output ranges between around 2 and $35 \mathrm{MW}$.

\section{Fixed-Grate Boilers}

Boilerhouses with two of the most commonly used types of fixed-grate boilers were chosen for testing in Phase I. The first has three cast iron boilers. The boilerhouse, built between 1975 and 1976, delivers hot water to three multistory buildings. These are natural draft boilers, and two doors on the boiler's front face regulate the flow of combustion air into the furnace. A lower door allows air to feed under the fuel grate; this is the primary supply. The position of this door is regulated manually or automatically to control firing rate and the boiler's output. The second air opening is smaller and is located above the combustion zone; this introduces air into the region of hot combustion products, reducing emissions of unburned gases. In normal practice, this door is kept closed. All three boilers exhaust flue gas into a common breaching ("settling") chamber and steel chimney.

The second boilerhouse contains steel fire-tube boilers. The grate is made of cast iron, is flat, and is not cooled. The boiler jacket is thermally insulated. These boilers are used for steamand water-heating systems, and are natural draft boilers with combustion air inlets similar to those of the cast iron boilers. Flue gases pass twice through fire tubes and then go via a smoke-box and a metal smoke conduit to a chimney.

The normal operational procedure for fixed-grate boilers consists in starting up the boiler and then spreading the required quantity of fuel on the grate surface. After this portion of fuel burns, the fire is not dumped; but again, the furnace is filled with fuel. The combustion rate and the boiler's output is regulated by operating the lower air-shutter in the furnace's front face, so controlling the entry of primary air. Combustion is evaluated by an operator, guided by observing the color of the flame in the furnace.

The only equipment for control and measurement on the boiler are thermometers and pressure gauges on the boiler's inlet and outlet. There are no devices for operation. Operators adjust the boiler's output to achieve a desired water temperature at the outlet based on outdoor temperature.

Three load levels and three fuels were tested at each boiler house. Because of the breaching arrangements at both of the boiler houses, the boilers could not be tested individually but, rather, as a boiler system. During the testing program, boilerhouse load, 
which essentially is determined by outdoor temperature, was nearly constant. The load on individual boilers was varied by changing the number operating. Effects of overfire air were evaluated on the cast iron boilers.

For the cast iron boilers, efficiencies ranged from $65 \%$ to $73 \%$. Efficiency was determined for the boiler system, and not for individual boilers. The highest efficiency of $73 \%$ was achieved at the medium load, i.e. with two boilers operating, using coke. The use of coal-coke mixtures reduces boiler efficiency and increases emission factors; these boilers should be fired with coke only.

For the steel boilers, the highest efficiencies were obtained in burning briquettes; the lowest in runs with coal fuel. Emissions with coal are much higher than for the cast iron boilers firing coke. Operating procedures did not affect the efficiency much. Briquettes should be used in these boilers. In all cases, overfire air should be used at the beginning of the firing cycle to minimize $\mathrm{CO}$ and volatile organics emissions.

Converting solid fuel-fired boilers to natural gas has been one of the more popular ways of eliminating low emission sources. In the Old Town part of Cracow, for example, which is densely built-up and inaccessible to district heating networks, it is practically the only way to eliminate these sources. Phase I examined the gas distribution network as well as the potential for natural gas conversions in two areas of the city. Home stoves can also be converted.

In Old Town, the existing gas distribution system has sufficient capacity to allow connections of coal- and coke-fired boilers. To convert about 20 boilers with a capacity of $16.3 \mathrm{MW}$ and to build the necessary pipelines and reducing stations, the cost would be approximately $\$ 2$ million USD.

The area just outside of Old Town has a large concentration of boiler houses and about 47 thousand home stoves. To connect 195 boiler houses ( $95 \mathrm{MW}$ ) and some of the stoves, the distribution system would need to be expanded and upgraded. The total cost for this part of Cracow would be $\$ 12.5$ million USD.

To encourage the conversions of these small boilers to natural gas, the city could limit the operation of solid fuel-fired boilers and could provide subsidies from the Community Fund for Environmental Protection to building owners wishing to convert. The gas distribution system within the center of Cracow is sufficient to allow conversions there; some expansion will be required in the immediately adjacent areas.

Stoker-Fired Boilers

Two types of stoker-fired boilers were selected for testing, a water boiler and a steam boiler.

Both boilers are the La Mont type and have a very similar design. La Mont type boilers are stoker-fired, water-tube, forced circulation boilers. Smaller boilers are designed as singlepass and larger ones (with rated capacities of 5 and $10 \mathrm{Gcal} / \mathrm{h}$ ) as two-pass boilers. The main 
components of the boiler are the heating system, mechanical grate, supporting structure with boiler casing, exhaust system for flue gases and a drum with steam boilers.

The heating system consists of coils inside the boiler that are welded to the inlet part of the lower collector chamber (water boilers) or to the drum (steam boilers). The inlets to the coils have jets to ensure a balanced distribution of water. The heating system is attached to the supporting steel structure, standing on the concrete foundation of the boiler. Coal is fed to the boiler from the top by a bucket conveyor. A coal gate maintains the height of the coal bed on the grate. A scale-type (single or double) grate is powered by an electric motor. A four-or twospeed mechanical gearbox controls the speed of the grate. Air to the boiler is not pre-heated; primary air is fed under the grate by a forced-draft fan.

Behind the boiler there is a battery of six cyclones and an induced draft fan. Additionally, one of the boilers tested has an overfire air fan blowing secondary air to the combustion chamber above the grate. Overfire air fans are commonly used with boilers of this type to promote mixing and complete combustion of volatile fuel components generated from the coal bed. Primary air is fed through the grate in zones and its distribution among the zones can be adjusted by manual dampers. These dampers match the distribution of air along the grate with the demand for air of the burning fuel bed. This type of adjustment is done very infrequently.

During normal operating procedure, the operators have only a very limited scope for regulating the boiler. The heat load on the boiler is regulated by the thickness of the fuel bed maintained by the coal gate. The speed of the mechanical grate is constant, adjusted to the kind of fuel fired. The overfire air fans at one of the boiler houses normally are not used, and the chimney draught normally is not regulated; these boilers are operated with extremely high levels of excess air. This is particularly true at low loads as air dampers often are set for high loads and then not adjusted as load is decreased. All firing controls are manual, and generally flue gas analyzers (for determining excess air) are not available at the sites.

Testing found efficiencies of around 50 to $60 \%$, much lower than the design values particularly at low load. The primary reason for the dramatic decrease in efficiency with decreasing load is the lack of air control, leading to extreme excess air levels at the reduced loads. For various fuels, attempts were made to optimize the grate speed. Optimizing the grate speed for a particular fuel and load was found to give an increase in efficiency by $7 \%$, even without airflow control.

In summary, the current stoker-fired boilers have unusually low efficiency due to limited instrumentation and controls and poor mechanical condition. Improvements in efficiency of about $15 \%$ could be obtained through the use of improved fuels in combination with an

optimization program. These boilers would benefit greatly from the addition of automatic controls.

Boiler Options

Of the more than 1,000 boilers in Cracow, 789 are within the range of the district heating 
network. Some of these serve industry and could not be connected to the network, and others are candidates for gas conversion. A total of 635 boilers with a capacity of $447.6 \mathrm{MW}$ could be eliminated by connecting them to the district network.

Two heat and power plants supply the district network, Lęg with a capacity of 1,460 MW and Skawina, with $220 \mathrm{MW}$ capacity. In addition, the plant at Sendzimir Steelworks supplies 36 MW to the district system. Distribution is through six subsystems, four connected to Łegg, one to Skawina, and one to Sendzimir. MPEC is Cracow's district heat distribution company.

Costs for extending the network and connecting boilers were developed in detail in Phase I. The average cost for connecting a boiler house to the network was about $\$ 84 / \mathrm{kW}$. Including boiler houses with a connection cost of $\$ 172 / \mathrm{kW}$ or less, about $87 \%$ of the proposed connections were found to be economically viable. A significant part of the increase in source capacity that would be required to extend the system can be found through energy conservation measures (see separate discussion below).

Some of the solid fuel-fired boiler houses in Cracow provide year-round steam to industry or are located too far from existing district networks for economical conversions. Thus Phase I also looked at possibilities for modernizing stoker-fired boilers.

Two teams of engineers, one Polish and one American, evaluated a boiler house in Krzesławice, owned by MPEC. The existing boiler house is an old facility, operated for more than 30 years; the condition of the boilers and auxiliaries forces MPEC to plan either a major overhaul or replacement of the existing equipment. When the selection was made, the boiler house could not operate at its rated maximum output nor cover peak demand declared by the steam customers. In its present state, the boiler house could not comply with pollution emissions standards. The emissions from this boiler house have been and still are a major problem for the surrounding residential areas, aggravated by the fact that the boiler house is operated all year.

Each of the designs involves replacing the existing boilers with new, modern ones and includes pollution control equipment; one of the options included oil-fired boilers. Costs of these options were high, especially those with only American components and labor. Capital costs of the oil-fired units were low, but operating costs would be non-competitive due to the high cost of oil in Poland.

\section{Energy Conservation Demonstration}

The Cracow building stock, typical of most of Poland, includes about 1,000 buildings made of prefabricated concrete panels, with little or no insulation. These buildings are usually heated by the municipal (pressurized hot water) district heat system or by local coal- or coke-fired boilers.

Weatherization measures may reduce the amount of heat needed in a building, but without accompanying controls, MPEC will deliver the same amount of heat; residents will just overheat and have to open their windows more often and no energy will be saved. Better 
controls will reduce energy used on mild days, but without weatherization, the capacity requirements for heat will not change, and the buildings may still be uncomfortable on cold days. In addition to technological "fixes," any efficiency program must include the economic incentives to motivate its implementation. Therefore, the Cracow conservation experiment had three major aspects:

- Building envelope improvements, to reduce the requirement for heat and improve comfort.

- Building-level control, to reduce the amount of heat delivered to the building during mild weather.

- Thermostatic controls of individual radiators, and incentives for the residents to use them.

Four adjacent "identical" buildings were selected for the project. Different combinations of energy efficiency measures were tried in each building over two heating seasons. To encourage use of thermostatic radiator valves, residents of two buildings received rebates if their energy use was below a certain pre-calculated target.

The building receiving the control, weatherization, and attic insulation measures reduced its seasonal heat energy consumption by over $21 \%$. The demonstration showed that the weatherization package (cost $\$ 45$ US per apartment) and roof insulation (cost $\$ 37$ US per apartment) were cost-effective, with simple payback of less that four years at current energy prices. Other measures tested, external insulation and basement insulation, did reduce energy consumption, but were not cost-effective.

For controls, the demonstration used thermostatic valves on radiators, as well as temperaturereset controls on building hydroelevators or heat exchangers. It is likely that comparable savings can be obtained by installing heat exchangers and infrared temperature-based controls in the network substation nodes, each of which serves from 5 to 25 buildings. This would lower the cost of control to about $\$ 80$ per apartment. It is also possible that a strategy of rebalancing the building heating system after weatherization, reducing the size of the orifice at the district heat connection (to reduce heat deliveries and lower the fixed capacity charge), and relying on MPEC's current control of the water temperature in the network may also accomplish most of what the more sophisticated controls do, but at a much lower cost.

The results suggest that conservation strategies will be key to many alternatives in the City of Cracow's plan to eliminate low-emissions sources:

- Connecting more customers to the MPEC network and eliminating local boilers without requiring construction of new combined heat and power plants.

- Reducing heat costs for customers converting from solid fuel heat sources to less polluting sources.

- Reducing heat demand so more customers can be served by existing gas and electric distribution systems. 
To fully encourage energy efficiency and exploit the demonstrated savings, the existing system of tariffs, subsidies and payments must be revised so the people who use heat 1) can control their usage, and 2) have an economic incentive to reduce their usage. The project has shown that this is indeed possible without putting a heavy financial burden on the residents.

\section{Comparing the Alternatives}

As part of Phase I, a spreadsheet model was used to examine the economic and environmental impacts of the various options for reducing pollution from the low-stack sources. The spreadsheet was designed as a screening tool to assist in making energyrelated policy decisions; the model has been used in other cities.

Two important simplifying assumptions are used in the model: 1) constant fuel and electric energy prices; and 2) averaged capital costs for conversions. In the spreadsheet, all of the low emissions sources in the city are placed into categories based on physical characteristics and the type of fuel used. Each category is defined by total fuel use, efficiency, fuel type and cost, emission factors, operating costs, and maintenance costs. New options are defined in the same way. For Cracow, this information was derived from the boiler and stove surveys and also from the engineering cost studies and the source testing program conducted as part of Phase I.

As options are selected, total costs and emissions are compared to the current, base state. Using a metric that incorporates capital and operating costs per unit of emission reduction, the following ranking of options was found:

- Use of improved fuels;

- Upgrade stoker-fired boilers with automatic controls and improved fuels;

- Connection to the district heating network;

- Conversion of coal-fired tile stoves to electric heating;

- Conversion of solid-fuel fired boilers to gas;

- Conversion of coal-fired stoves to gas-fired units; and

- Modernization of stoker boilers.

The spreadsheet was also used to examine scenarios for the city. For example, elimination of almost all low sources was evaluated. As expected, the costs for such a scenario are very high and it is unlikely to be implemented in the near- to mid-term. Evaluation of other scenarios, which include some equipment conversions but focus more on low- or no-cost measures such as improved fuels, shows that emissions from low sources can be significantly reduced in the interim.

The City of Cracow is developing a long-range plan for the elimination of low-stack sources. The City is also promoting conversions of home stoves, and is converting some boilers to gas. These activities, and other recent events in Cracow, are discussed in Chapter 5. 
The companies and projects selected for Phase III cost-sharing had two major goals - to help reduce pollution in Krakow and to establish joint-venture companies that would continue to thrive in the region after DOE cost-sharing ended. Each company's unique characteristics and strengths helped it meet the challenges of finding suitable Polish partners and implementing its project. The projects met with varying degrees of success, but all have expanded U.S. presence in Poland and have contributed demonstrable improvements to the air quality in Krakow. This chapter presents achievements of four projects.

\section{Control Techtronics International, Inc.}

Control Techtronics International, Inc. (CTII) is a controls manufacturing firm based in Harrisburg, Pennsylvania. The company, established in 1984, specializes in the design, development, manufacture, and application of advanced combustion and process control systems. CTII is very active in the U.S. market as well as in specific growth markets worldwide.

Under this project, the CTII team sought to introduce to the Polish market their advanced control technology for stoker-fired boilers. Controls were installed on five stoker-fired coal boilers at the Balicka boiler house. This plant is owned by MPEC, Cracow's district heating company, and supplies heat to a nearby housing development and process steam to local industry. Three hot water and two steam boilers were fitted with the automatic controls. The project also included operator training.

Partners in the project included two Polish companies, Energoaparatura (ENAP) and Naftokrak-Naftobudowa (NK-NB). ENAP was responsible for the control panel fabrication and NK-NB for the controls installation. The controls and inverters were manufactured in the U.S. by CTII. Pennsylvania State University and Cracow's Polytechnic University worked together to translate technical manuals and provide operator training. Cracow Polytechnic also provided performance testing of the boilers.

\section{Automated Boiler Controls}

Stoker-fired boilers are commonly used throughout Central and Eastern Europe. Small and mid-sized coal-fired power plants utilize traveling grate stokers to produce steam or hot water that is used by district heating systems and industries. These boilers were originally derived from hand-fired boilers as a method of extending the capacity range to larger sizes [6]. Advantages of stokers include fuel flexibility and relatively modest requirements for fuel preparation. Stokers have been used for a wide range of fuels including coal, wood waste, rice hulls, peach pits, and coffee grounds as well as residential and commercial refuse [7]. 
In Cracow one way to address the air pollution emissions from the existing stoker boiler population is simply to replace the stoker plants. However there are some points in favor of keeping the existing stoker plants. Beyond conversion investment and low operating cost the performance of these plants may be improved through improved operations. Dramatic improvements can be made to the efficiency and emissions level of these existing plants for significantly less money than replacement cost. This has essentially been the motivation behind the Control Techtronics project.

The boilers included in the Control Techtronics project were tested as part of Phase I of this program to provide baseline performance and emissions data. The boilers were in very typical condition - furnace pressure, firing rate, and excess air were all manually controlled, allowing operators limited regulation of the combustion process. Testing was done at three load levels. Efficiencies were $51 \%$ at minimum load, $63 \%$ at average load, and $74 \%$ at maximum load for the WR-10 boilers. In normal operations combustion air flow was not reduced as firing rate decreased in response to normal load changes. The result is very high excess air levels - to $500 \%$ - at low load. This testing was done with a coal duf that was normally used in the stoker boilers. Testing was also performed with different coals and with greater attention to optimizing grate speed and controlling combustion air flow during the tests. In these tests, efficiencies were about $73 \%$ at all load levels.

As discussed in the previous chapter, Phase I of the Cracow program included a comparison of the costs and benefits of a wide range of options for addressing the low emission sources. With the analysis tool developed for the program, the Control Techtronics project specifically was shown to provide emission reductions with a net cost savings for the boiler house owners [8].

Another important aspect of the CTII project is operator training. Even with advanced controls and proper fuel, efficiency and emissions benefits can be realized through proper operating procedures. The basis for the operator training program was educational material developed by the Penn State Facilities Engineering Institute in the U.S. Team members worked closely with faculty members at Cracow Polytechnic University to translate this educational material and adapt it to Polish conditions. Training sessions were implemented in Cracow, by the Polytechnic University. These training materials will serve as one of the enduring tools for improving performance of these boilers.

Installation of Controls at the Balicka Boiler House

The Balicka boiler house was built over the 1968-1972 time frame and has three Polish WR 10 boilers and two WLM 2.5 hot water boilers supplying heat to the residential buildings of the Widok housing development and two PLM 2.5 steam boilers supplying process steam to nearby industries. Two complete automatic control systems were installed - one managing the operation of the three WR 10 boilers, and the second managing two PLM 2.5 steam boilers. The measured control parameters are: water flow and outlet temperature for water boilers or steam flow and pressure for steam boilers, combustion chamber pressure, and flue gas oxygen content as a measure of excess air. On each of the boilers the automatic system controls three parameters: stoker grate speed 
(to adjust firing rate), forced draft fan speed, and induced draft fan speed. After the installation, one of the WR 10 and one of the PLM 2.5 boilers at Balicka were tested for efficiency and emissions. Results show that use of controls reduced particulate emissions by 85 percent and resulted in energy savings of 25 percent. The graphs in Figure 3-1 illustrate these dramatic results.

\section{Project Impact}

During the 1995-1996 winter, the Balicka boiler house accounted for 8 percent of the coal burned in Cracow's stokers and 8 percent of the particulate emissions from stoker boilers. Reducing particulate emissions by 85.5 percent at Balicka also reduced overall stoker emissions in Cracow by 7 percent. If all stokers were similarly upgraded, total particulate emissions in Cracow would be reduced by 31 percent. In addition to the energy and emissions reductions, the boilers can now be operated at lower loads than previously. With the fuel reduction due to improved efficiency, this project has a payback of about 2 years. Clearly, automated controls on the stoker-fired boilers is a viable, cost-effective approach to reducing particulate emissions.

\section{Activities Beyond the Project}

CTII has formed a joint-venture subsidiary, CTI-Polska, to continue its presence in the region. CTI-Polska is now well established in the Polish and Eastern European markets to represent CTII sales and local engineering/field service objectives. From Poland, CTII has gone East to the middle of Siberia for its largest job to date, in conjunction with an informal joint venture with a Polish subsidiary, Neko-CTI. The city of Novokuznetsk has nine CTII control systems installed in five boiler houses around the city. Poland and Russia combine to form the largest market in the world for these control systems and CTIPolska and Neko-CTI have been established to service this market. 

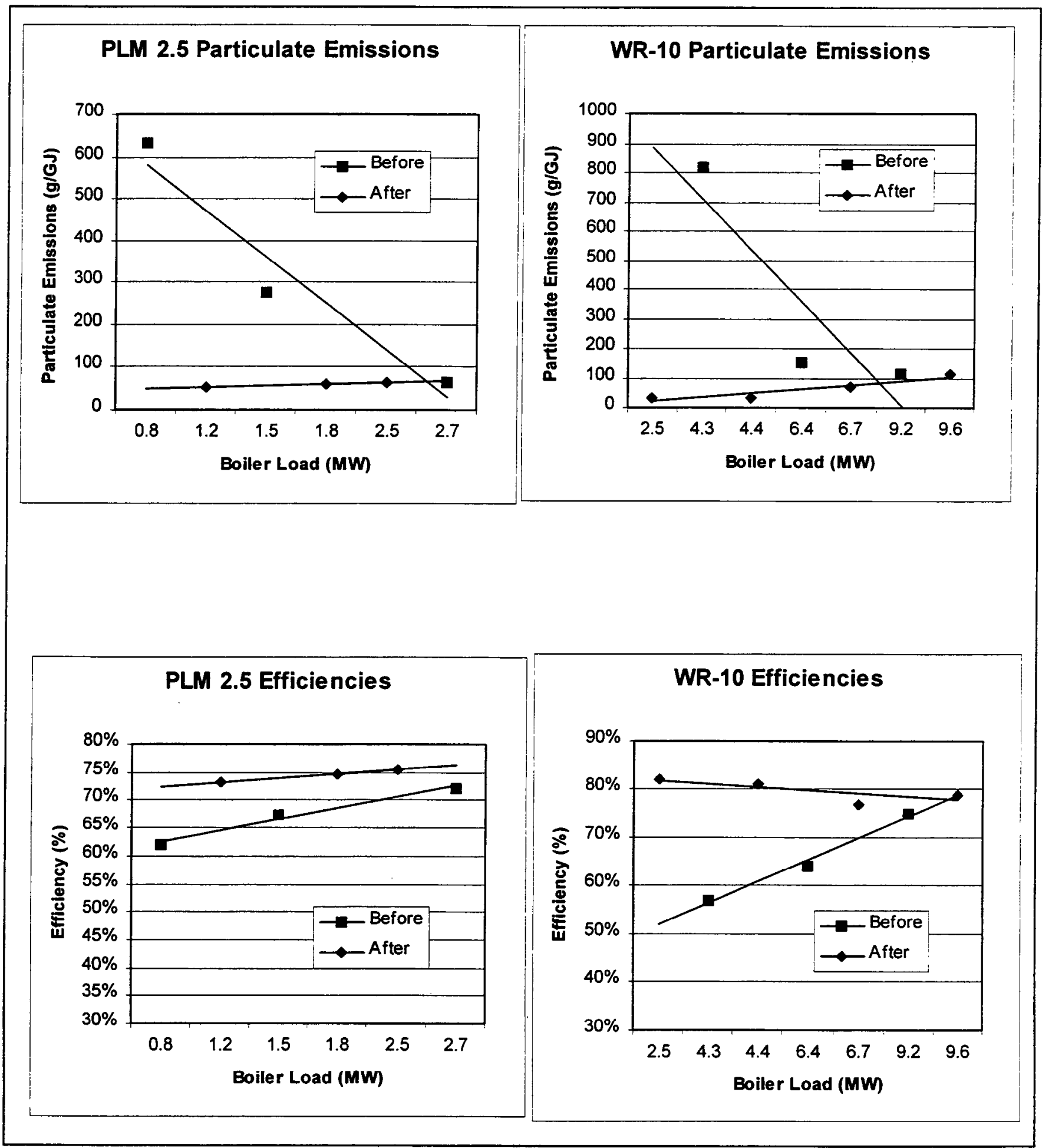

Figure 3-1. Results at Balicka 


\section{Honeywell}

Honeywell is a major worldwide controls manufacturer, established in Minneapolis in 1885. It's first European subsidiary began in 1934; now Honeywell operates in 95 countries.

Honeywell's project produced very significant accomplishments in enhancement of district heating and reduction of pollution from local coal-fired boilers. While their work reached many different project sites, the main area was the Balicka District Heating Network. This local network is isolated from Cracow's main district heating network and is supplied with heat from the Balicka boiler house on Lindego Street. This is the same boiler house where CTII installed combustion controls and Honeywell and CTII cooperated in the area of control interface. The following table provides a breakdown of the load served by the MPEC Balicka boiler house:

\section{Consumer Group}

WIDOK Housing Cooperative Industry

Widok Zarzecze Estate - single family houses Detached single family houses

\section{$\%$ of Consumption}

10.0

5.0

The Widok Housing Cooperative includes 22 buildings with 2,750 apartments, and houses 7,500 residents. Prior to the program, each building had hydroelevator nodes in the basement which mix return water with very hot district heat system water for distribution to radiators. In the apartments there was no possibility for individual room temperature control.

Beyond the Balicka District Heating System the Honeywell project involved the Bienczyce Housing Estate --another coop with 47 residential buildings and 16,000 inhabitants, Jana Pawla II Hospital, Narutowicza Hospital, and many other sites. Specific accomplishments of this project include:

- Installation of controls at the Balicka boiler house covering the internal mixing node, the water purification system, supervision of the entire Balicka District, and measurement of flue gas composition, and flow.

- Installation of 50 heat exchangers replacing hydroelevators in buildings of the Widok housing estate (installed capacity $14.05 \mathrm{MW}$ )

- Installation of 14 heat exchanger stations and connection to the Balicka network of the Academy of Agriculture and several public buildings.

- Upgrading controls at an existing heat exchanger serving the Widok Zarzecze housing estate. 
- Complete reconstruction of heat exchangers and heat distribution at Jana Pawla II and Narotowicza hospitals. Central control systems were installed at both of these sites.

- Installation of a separate supervisory and data collection system for heat meters located in the Balicka area.

- Installation of 80 building heat meters for the Widok Zarzecze housing estate.

- Upgrading internal building heating systems in: Widok housing estate (25 buildings), Widok Zarzecze Housing estate ( 25 buildings) and the Bienczyce Housing Estate (8 multistory residential buildings). This work included removing, cleaning, and reinstalling radiators, installation of Thermostatic Radiator Valves (TRVs), testing and restarting of the system, and training of the residents. In the Balicka area alone (excluding Bienczyce) 13,525 TRVs were installed.

- Removal of 4 large local boiler houses and replacement with 4 heat exchanger installations (11.8 MW capacity). These boilers were located on the main network and Honeywell cooperated with ECKSA in this case. ECKSA is the company which operates Łeg - the cogeneration plant that supplies the city's main district heating network.

- Cooperation with ECKSA on the installation of 85 additional heat exchanger substations allowing the elimination of local coal-fired boiler houses (41.0 MW capacity). These sites were again connected to the main network. Honeywell's role at these sites was limited to delivery of instrumentation and control and related project services such as project management, engineering, installation and start-up.

\section{Project Impacts}

At the Widok Housing Estate two methods were used to estimate the impact of replacement of hydroelevators with controlled heat exchangers, installation of TRVs in apartments and general overhaul of internal heating systems. In the first method, energy use in modernized buildings was compared to that in very similar buildings that had not been modernized. In the second method, energy use in specific buildings was compared before and after modernization. Modernized buildings used 7-17\% less energy -- although, in some cases, savings over $25 \%$ were determined. Considering all of the data analyzed, Honeywell estimates an average energy savings in buildings of $15 \%$. Honeywell further estimates that energy use will be reduced an additional $5 \%$ in the future as residents become more experienced with the TRVs.

The improvements made to the district heating network supplied by Balicka resulted in significant benefits in addition to those achieved by CTIl's project to modernize the boiler's 
controls. Overall, the fuel reduction at the Balicka boiler house is estimated to be about 33 percent, or $5,500 \mathrm{Mg}$ per year. Also, the Honeywell project resulted in a reduction in electricity consumption at Balicka of 29 percent. The work with ECKSA which eliminated boiler houses by connecting them to Cracow's main district system resulted in an additional reduction of $690 \mathrm{Mg}$ of particulate emissions per year.

Emissions for the entire city of Cracow have been significantly reduced by these projects. Percentage reductions for the city are:

$\begin{array}{lr}\text { Particulates: } & 9.7 \% \\ \mathrm{SO}_{2} \text { : } & 10.4 \% \\ \mathrm{CO}: & 5.3 \% \\ \mathrm{NO}_{\mathbf{x}}: & 6.9 \%\end{array}$

\section{Continued Presence in Poland and Eastern Europe}

Honeywell has studied the market for conservation products in Poland and Eastern Europe. Honeywell used this project to strengthen its position in the Polish and Eastern European markets. Honeywell's presence in Poland has evolved from an entrepreneurial unit in an emerging market to an established ISO-certified affiliate. By developing local resources during the course of this project, Honeywell's affiliate in Poland has grown, formed local partnerships with subcontractors, and developed an understanding of the political, legal, financial and economic factors that shape the energy conservation market in Poland. To extend its capabilities, Honeywell created Honeywell Poland ESCO. This will not only help provide financing, but assists customers in assessing their requirements, provides comprehensive technical solutions, and manages cash flows and entire projects.

In addition, Honeywell set up a TRV assembly facility in Cracow in cooperation with the Polish firm Dempan. Honeywell expects to capture a significant share of the growing TRV market in Poland as well as Eastern Europe. It is estimated that the market in Poland for TRVs will be 1.5 -2 million units per year over the next five years - the largest in Eastern Europe.

Honeywell is utilizing Cracow as an operational demonstration site to secure further work. Work on Cracow's main district heating network is likely to continue.

\section{Shooshanian Engineering Associates, Inc.}

Shooshanian Engineering is a mechanical and electrical engineering firm specializing in study, design, and construction services for commercial, industrial and institutional clients. Shooshanian also offers telecommunication design and construction administration services. Shooshanian was founded in 1961 and is based in Boston, Massachusetts. Shooshanian teamed up with MPEC, Cracow's district heat distribution company, and Polinvest, Ltd., a Polish economic and legal consulting firm, to reduce pollution levels in the city of Cracow through the retirement of coal-fired (hand and mechanically-stoked) 
boiler houses. This was achieved by identifying attractive candidates and connecting them to the Cracow district heating system, thus permitting them to eliminate boiler operations.

Because some of the targeted boiler houses were large, the capacity of the district heating network required enhancement at strategic locations. Consequently, project construction work also included extension of and improvements to Cracow's central station district heating system. Shooshanian also provided marketing and customer service training to MPEC.

Five major tasks comprised the scope of the project. These are:

- $\quad$ identification and evaluation of potential district heating clients, development of client offering (including engineering and economic analyses), and negotiation of binding agreements;

- engineering design of new client connections;

- construction activities including hot water distribution enhancement and connection of clients;

- $\quad$ training of MPEC personnel in:

- marketing, customer services, and strategic planning practices, including assistance in establishing a Marketing Department and a Customer Service Office,

- energy conservation studies, and

- project management and financing techniques; and

- joint venture formulation including market research, investigation of potential clients and projects, joint services proposal development, financial planning and legal issues analyses.

Thirty-three facilities at 26 sites within Cracow were identified, negotiated with, and connected to the main district heating network. Infrastructure improvements included not only the distribution piping, but also all required pumps, heat exchangers, metering, controls, and other items needed to make the system functional, reliable and efficient. Prominent sites included: Dworzec PKP (Cracow Main Rail Station), Akademia Rolnicza (Academy of Agriculture campus at 29 Listopada), the Nursing Home Complex of Helclów Street, and several other institutional, commercial and residential buildings.

As a result of site connection to the central heating network, a total of approximately 40.8 $\mathrm{MW}$ of coal-fired boilers have been retired, abandoned, or demolished. The peak heating capacity shifted to the central network is $28.4 \mathrm{MW}$. Emission reductions associated with the load shift are:

- particulates -

- sulfur oxides -
265.6 metric tons/year

258.3 metric tons/year 
- nitrogen oxides - 45.1 metric tons/year

- carbon monoxide - 388.8 metric tons/year.

Marketing Development and Training

MPEC has only recently been forced to compete for customers in a marketplace that has dramatically changed as Poland has moved away from a centrally planned economy. The issues of marketing, public relations, negotiation, research, and customer service all play important roles in expanding the district heating network. The development of a marketing strategy for MPEC was critical to the success of this project.

Shooshanian developed a Marketing and Customer Service Training Manual for MPEC to assist the company in defining the services which should be provided in a competitive marketplace. In addition, marketing and customer service training was provided. Because there was no clear means by which even existing customers could communicate questions or concerns, MPEC was encouraged to establish a Customer Service office. Training was also provided in strategic planning and in how to conduct an energy conservation study. MPEC is now well-positioned to provide customers with value added services and to develop strategies and techniques to succeed in a competitive marketplace.

\section{Future Activities}

Discussions of future cooperation among the three companies - Shooshanian, MPEC, and Polinvest - have been ongoing throughout the project. Continued cooperation is deemed highly compatible with the strategic goals of each firm. Several scenarios for future cooperation have been identified and evaluated; creation of a formal joint venture is not feasible at this time. Nonetheless, the companies are continuing discussions and intend to continue working on potential future joint projects in the area of energy efficiency and environmental protection.

\section{LSR Technologies, Inc.}

LSR Technologies, Inc. of Acton, Massachusetts is a small company specializing in the development of advanced technology for physical and chemical separations. Beginning in 1989 and with support from the U.S. Department of Energy and the U.S. Environmental Protection Agency, LSR developed a new concept for mechanical dust collection - the Core Separator. The LSR work in Poland has involved the refit of Core Separators to existing, coal-fired boilers.

In Poland mechanical particulate collectors have traditionally been used over more efficient control devices in industrial applications due to lower initial and operating costs. The Core Separator is more efficient than conventional mechanical collectors. Dust emissions from this device are typically 3-6 times lower than from even the best cyclone collectors. Its performance approaches that of fabric filters and electrostatic precipitators (ESP), but at much lower cost. 
A simplified schematic of the Core Separator system is shown in Figure 3-2. The system includes two conventional components, a cyclone collector for extracting solids and a fan for flow recirculation. A Core Separator component usually includes a multitude of cylindrical units. Each unit has a single inlet for the stream to be treated and two outlets, one for the cleaned gas stream on the other containing a highly concentrated recirculation stream. The dust-laden recirculation stream is fed to the cyclone and then returns again by means of the fan. The processes of separation and collection are accomplished separately in different components. The Core Separator cleans the inlet stream and detains dust particles in the system. Since its efficiency is quite high, the dust particles cannot leave the system. They recirculate again and again until collected in the cyclone. Historically, conventional cyclone dust collectors have been ineffective in removing dust particles with diameters below 10 microns. In comparison, the Core Separator is able to remove a high percentage of particles even at 2-3 microns. In Poland, the cyclone dust collectors commonly used on coal-fired stoker boilers typically have an efficiency for particulate capture of $75-80 \%$. Applied to the same boilers, the Core Separator achieves $94-98 \%$ capture [9].

The Core Separator system can actually be arranged in a variety of configurations depending on process conditions, required performance, inlet dust concentration, abrasiveness of solids, etc. A typical arrangement is shown in Figure 3-3.

In Poland, LSR has cooperated primarily with two organizations: FEWE - the Polish Foundation for Energy Efficiency based in Katowice, Poland and Ecolnstal an equipment manufacturing firm in Poznan. FEWE is an independent and non-profit organization formed at the end of 1990. The organizer of the Foundation has been Battelle Memorial Institute - Pacific Northwest Laboratories from the U.S. FEWE is involved in projects throughout Poland with three regional centers in: Warsaw, Cracow, and Katowice. The general scope of the activities of FEWE include:

- Studies and analyses to support energy efficiency; 
- Support for development of the private sector including joint ventures with foreign companies in order to transfer into Poland new energy efficiency technologies, know-how and expertise;

- Training and education of Polish professionals as well as execution of demonstration projects within the energy efficiency field; and

- Public education.

As part of their cooperation with LSR, FEWE provided industry knowledge and contacts and marketing support.

Ecolnstal began their cooperation in this project as a manufacturer of pollution control equipment with a total of 30 employees. Under this program LSR transferred to Ecolnstal the technology for producing and installing the Core Separators. Through the program Ecolnstal assumed full responsibility for marketing, application engineering, detailed site design, installation, startup, and performance testing.

As a formal part of this program, the LSR team completed the installation of a Core Separator particulate removal systems at two sites in Cracow. This includes one stoker fired boiler located at the plant of a motor manufacturing company - Armatura - and three stoker-fired boilers located in a service facility of the national bus company - MPK. At

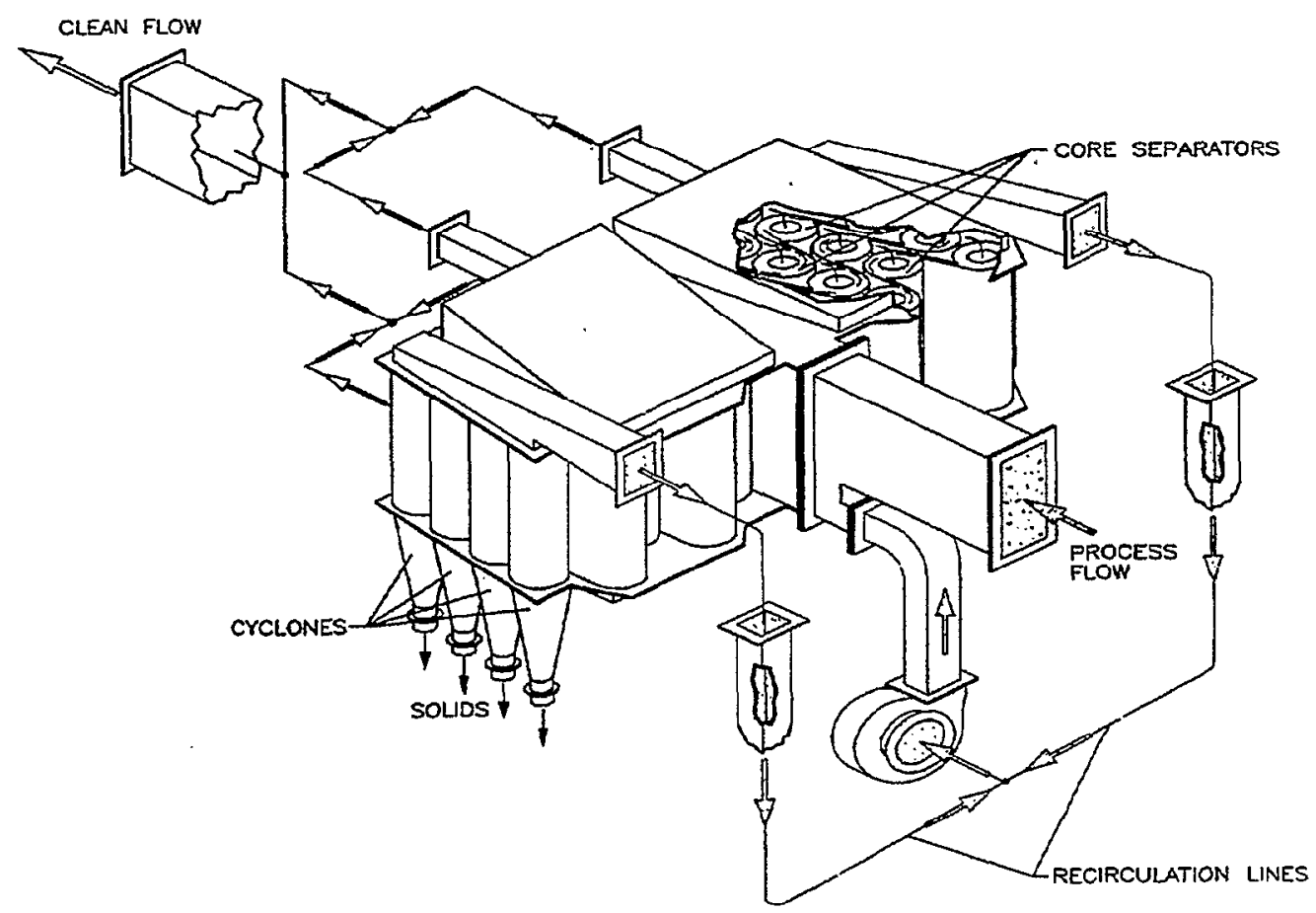

Figure 3-3. Typical Core Separator Arrangement 


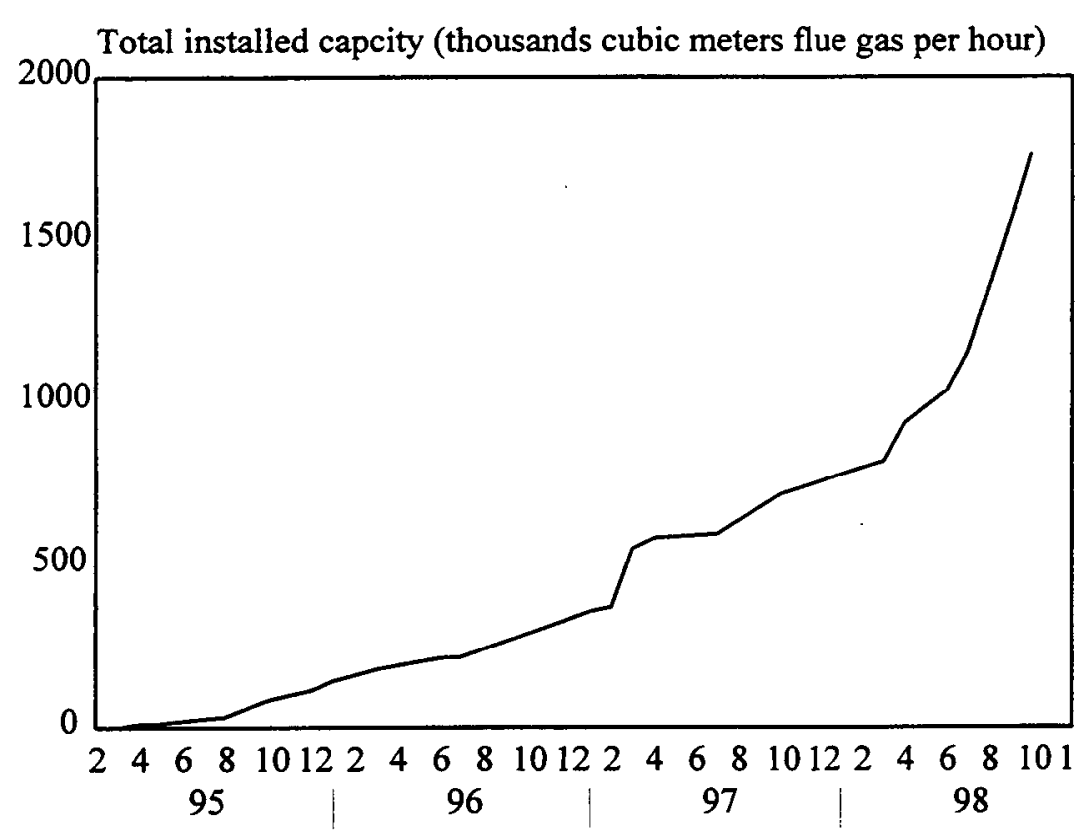

Figure 3-4. Trend in Installed Capacity of Core Separators in Poland each of these sites testing was done to document actual performance. At Armatura the boiler has a nominal capacity of $6 \mathrm{MW}$ and measured particulate removal efficiency was $95.4 \%$. At MPK the total boiler capacity is $1.5 \mathrm{M} \mathrm{W}$. Two of the three boilers were tested at MPK and measured particulate removal efficiency was $91.4 \%$ and $96.0 \%$.

Beyond the formal scope of this program, Eco-Instal has completed 36 additional Core Separator installations and 16 additional installations are in progress. Table 1 provides a project list to mid-1998. Total coal consumption at these sites is estimated at 557,000 metric tons per year. The growth rate of the Core Separator business of Eco-Instal has been very impressive. Figure 3-4 shows the trend in Core Separator total installed capacity since the project started (Note: data in the second half of 1998 is projected, based on projects in progress).

Project Impact

For the two sites in Cracow formally included in this program the particulate reduction impact can be estimated from the performance test results and average operating parameters for boilers of this type [3]. Specific assumptions include:

boiler efficiency $=63 \%$ (based on lower heating value, European method)

coal heating value $=19.014 \mathrm{MJ} / \mathrm{kg}$ (lower heating value)

capacity factor $=.186$

uncontrolled particulate emission factor $=.0249 \mathrm{~kg}$ per $\mathrm{kg}$ of coal

The capacity factor here is the annual energy output divided by the energy which would be output if the boiler ran at full rated load for a solid year. The combined capacity for the two sites is $7.5 \mathrm{MW}$. Using this and the above assumptions, the uncontrolled particulate emissions are 91.36 metric tons per year.

For some of the Core Separator installations in Poland no particulate control devices were installed in the baseline case. More typically, however, mechanical cyclones were installed and were in relatively poor condition. Assuming preexisting cyclones with a 
particulate collection efficiency of $70 \%$, the particulate emissions for the two Cracow sites would be 27.4 metric tons per year. After the installation of the Core Separators with collection efficiency of $95 \%$, emissions are reduced to 4.6 metric tons per year. The net benefit of the work at these two sites, then, is $27.4-4.6$ or 22.8 metric tons per year.

The impacts of the LSR project are much greater if installations outside of this program are also considered. The total coal consumption for all of the sites listed in Table 3-1 is estimated to be 557,000 metric tons per year. This exceeds annual coal consumption in all of the Low Emission Sources in Cracow. Particulate capture in Core Separators installed to date across Poland is estimated to be 2,775 metric tons and this exceeds by 2.5 times particulate emissions from all stoker-fired boilers in Cracow in 1991 (1,083 metric tons).

Activities Beyond the Project

Eco-Instal is continuing to market and install Core Separators in Poland and is expanding throughout Europe. As a result of the Core Separator activity employment at Eco-Instal has increased from 30 to 100 employees. In 1997, Ecolnstal received a national environmental award, largely due to their sales of Core Separators. 
Table 3-1. LSR Core Separators Produced by Ecolnstal

\section{No.of}

1. PEC Oborniki

2. EXBUD Tamow

3. Kombinat RSP Czempin

4. PEC Knurow

5. MPK Krakow

6. Armatura Krakow

7. Inst Non Ferrous Metals 1

8. Matizol Gorlice 2

9. Odlewnia Zeliwa 1

10. Argenichem Opalenica 1

11. Klimawentex Rzeszow 3

12. Budostal Krakow 1

13. Zaklad Farbiarski Warsaw 1

14. Fiat Auto Poland 1

15. Krakodlew-Krakow 1

16. Cementownia Strzelce 1

17. Zembiec Zembcu 1

18. PDM-Koscian 1

19. EkoBud-Grudziadz 1

20. ExBud-Tarnow 1

21. Skelja Eko-Ostrow 1

22. Czech Technical University 1

23. Firma Dragowa Kutnie 1

24. PZL-Wola Warsaw 2

25. Sp. Energ. S.A. Moszczenica 1

26. Ferney Spinning Mills, Mauritius 1

27. ZRD Poznan

28. MZC Dzierzoniow 3

29. S.P. Energ. S.A. Pniowck 1

30. Zak. Energ. Ciepinej. Katowice 1

31. Dacwoo Lublin

2

32. Huta Im. Eediera Sosnowicc 2

33. Cukrownia Raciborz
Initial

Operation

$4 / 95$

$5 / 95,6 / 96$

$8 / 95$

$10 / 95$

$1 / 96$

$1 / 96$

$6 / 96$

$3 / 96$

$3 / 96$

$3 / 96$

$6 / 96$

$6 / 96$

6/96

$1 / 97$

2/97

$2 / 97$

$3 / 97$

$4 / 97$

$4 / 97$

$4 / 97$

$7 / 97$

$10 / 95$

$3 / 97$

$3 / 97$

$10 / 97$

$12 / 95$

$3 / 98$

$4 / 98$

$6 / 98$

$7 / 98$

9/98

$9 / 98$

$10 / 98$
Capacity $\left(\mathrm{m}^{3} / \mathrm{h}\right)$

10,000

7,300

18,000

50,000

5,600

22,600

2,000

10,000

25,000

800

3,000

21,600

9,000

140,000

8,000

6,400

35,000

21,600

3,500

5,800

13,600

2,500

45,000

100,400

120,000

30,000

100,000

108,000

110,000

120,000

220,000

180,000

$\underline{210,000}$

$1,764,700$

\section{Application}

WR-2.5 Stoker Boiler

Fluidized Bed Boilers

WCO-80 Stoker Boilers

WR-10 Stoker Boiler

WRC-80 Stoker Boiler

WR-5 Stoker Boiler

Copper Smelter

Asphalt Plant Drier

OKR-5 Stoker Boiler

Smelting Furnace

Glassmelting/Sanderdust

Rotary Drier/Bentonite

PCO-60 Heating Boilers

WR-25 Stoker Boiler

Rotary Drier/Sand

Cement Kiln Drier

Rotary Drier/Bentonite

Asphalt Dryer

SR-15 Boiler

Fluidized Bed Boiler

WLM-2.5 Boiler

Fluidized Bed Boiler

Rotary Drier/Asphalt

WR-5 Boilers

PWRp 20 Boiler

Stoker Boiler

Rotary Dryer/Asphalt

WR-5 Boilers

WR-25 Boiler

WR-25 Boiler

EKM-50 Boiler

OR-32 Boilers

OR-32 Boilers 
The Cracow Clean Fossil Fuels and Energy Efficiency Program started in 1991. At that time, air pollution in the center of Cracow regularly exceeded Polish standards. The low stack sources accounted for about $35-40 \%$ of the city's pollution during the heating season. Energy prices were rising rapidly, and although there was growing awareness of conservation, there were no widely accepted approaches to conserving energy.

Since then, Cracow's air quality has significantly improved. A number of factors have worked together to accomplish this, many of them directly related to the success of the Program. In particular, information developed by the Program has been useful to the City, the Voivodeship (province), and the utilities in planning the most effective ways to minimize pollution from the low stack sources. While some of the funding for the Program was used to directly eliminate or reduce the impact of low sources, a more important effect was the demonstration of the efficacy of these measures, which inspired Polish funding of many more activities. Similarly, the energy conservation demonstration project showed what should be done to effectively conserve energy in residential buildings and documented actual costs and savings.

The public relations activities of the Program not only provided awareness of Program activities, but also sparked debate among Cracovians about the best ways to reduce emissions. The residents and politicians of the City must be credited with the dramatic improvements in the City's environment; it is their determination that has turned the information from the Program into a citywide success.

\section{Reconstruction and Modernization of the District Heating System}

At the end of the 1980s MPEC (Cracow District Heating Company) was in a difficult market situation characterized by:

- limited financial resources

- poor technical condition of the system

- no access to modern technologies

- complex legal and ownership status

- inappropriate tariff system

- no measurement equipment in district heating substations (nodes)

In 1990 the company's situation began to change. Cooperation with the World Bank was concluded and a long-term plan was developed to modernize the system. As a result, the company obtained a credit of USD $25 \mathrm{M}$. In 1994 the company was transformed into a joint stock company and the following steps were taken to reconstruct and modernize the district heating system.

First, the plan of projects was verified; consequently projects and tasks that proved unnecessary or too costly were eliminated. Then the construction of necessary sections of 
districtheating mains was completed, including the connection between the Skawina Main and the Western Main, thus increasing the potential load on the Skawina CHP Plant.

In 1990-1992 the tariff system was changed; the lump-sum payment per square meter of heated space was abandoned in favor of a two-tier tariff consisting of the payment for the power ordered (in MW) and for the heat actually consumed (in GJ). Heat meters were installed in all connection nodes, which made it possible to measure the amount of heat actually consumed.

At the same time, the system's water losses were reduced by replacing the gland expansion joints with bellows expansion joints, and installing new network fittings. Heat supply reliability was increased by gradual replacement of sections of the network placed in channels with preinsulated pipes.

Finally, automation of the system's operation was implemented. Sixty-seven collective heat exchanger stations were replaced, followed by gradual replacement of hydroelevators with heat exchangers.

\section{Gaining New Customers by MPEC and ECK}

One of priorities of the investment policy of MPEC S.A. and ECK S.A. (Cracow combined heat and power company) is to connect to the district heating network the largest possible number of new customers. To this end the following courses of action are taken:

- connecting new buildings

- connecting local boiler houses

- $\quad$ extending the range of services to include domestic hot water throughout the year

- extending the range of services to include air conditioning and ventilation.

\section{Availability of Energy Carriers}

By the end of the 1980s, solid fuels, and primarily bituminous coal, belonged to the key energy carriers. There were many local boiler houses and stoves. Recent years, however, have witnessed a tendency to use environmentally friendly energy carriers which are also convenient for users and require no permanent attendance. In the 1990s natural gas has become a generally available energy carrier, while heating oil became popular in the peripheral areas of the city. The municipal district heating network remains, however, the principle source of energy used for heating.

\section{Energy Conservation Activities}

At the end of the 1997 , Cracow had 32,546 residential buildings, including $70 \%$ single-family houses and $30 \%$ multi-family houses. There are 244,651 apartments in Cracow, of that $90 \%$ is in multi-family houses. The newest apartments, those constructed in the 1990s and 1980s, account for $5 \%$ of all apartments, while those built in the 1970 s account for $37 \%$. Buildings 
constructed in the 1950 s and 1960 s account for $32 \%$, those built before 1945 account for $32 \%$, while buildings constructed before 1918 account for $5 \%$. The ownership structure of these apartments is as follows: $46 \%$ are owned by housing co-operatives, $15 \%$ by the municipality, $6 \%$ by enterprises, and $33 \%$ are privately-owned.

Central heating installations exist in $80.1 \%$ of buildings. About $60 \%$ of the apartments are supplied with heat from the municipal district heating network. The buildings' heating facilities and insulation standard are closely related to the year of construction. In general, only the buildings of the 1990 s meet current thermoinsulation standards and have heating installations with measurement and control equipment.

In 1991 most residents paid for heat based on the area of their apartments rather than on the amount of heat actually used. There were no thermostats, and the temperature of the water sent from the district utility's heat source determined the amount of heat delivered to a building. There had been no conservation demonstration in Cracow.

By 1996, many buildings are equipped with heat meters and an increasing number of households pay for actual heat consumption. Now almost all housing cooperatives are implementing energy conservation measures. These include modernizing heat exchangers and internal heating installations, installing measurement devices, window sealing, and ceiling and wall insulation. There is some governmental funding for this, but for the most part the cooperatives are using their own funds. The conservation demonstration undertaken as part of this Program, by clearly showing the effectiveness of improving a building's efficiency, contributed to the high level of interest in these activities.

\section{Changes in Environmental Protection Regulations}

The Act on Environmental Protection and Management was passed in 1980. The Act made it obligatory for organizations/companies to operate based on a "Permissible Emission Order" determining types and quantities of pollutants discharged to the atmosphere. The ordinance by the Minister of Environmental Protection, Natural Resources and Forestry of 1990 determined the amounts of sulfur dioxide, nitrogen dioxide and particulates formed during combustion of fuels in the process of energy generation. The ordinance imposed new, stringent requirements to be met by new combustion installations, i.e. those erected after 31 December 1994. For the existing installations, a two-stage procedure was introduced; lenient requirements were to remain in force by 31 December 1997, and stringent ones after that date. In 1998 the Act on Environmental Protection was amended by the Minister's ordinance, which further reduced the permissible levels of permissible industrial emissions to the atmosphere.

\section{Low Emission Sources}

In July 1998, the boiler database was updated to reflect the status at the end of December 1997. The up-dated information, collected in the form of questionnaires, was entered into the computer database and presented in the form of summaries and lists, the most important of which were used to prepare this report and the long-range plan for the part of Cracow located between the second ring road and the administrative limits of the city (see Chapter 5). A new 
and to economic transformation manifested by a collapse in industrial output and an increase in energy prices, on the other hand. The shift towards realistic cost-based prices forced energy users to take energy conservation measures and to reduce the costs of heating. Companies involved in production and distribution of energy (and its carriers) faced the necessity of gaining new customers in the shrinking market. New technical solutions and high quality heating appliances were offered.

The work conducted under Phase I of the American-Polish Program for Elimination of Low Emissions established a basis for investment projects in this sector: the situation that prevailed at that time in low emissions and municipal infrastructure was surveyed and described. Based on technical and economic analyses, the most effective technical options were identified, along with obstacles and technical, economic and legal limitations, and methods of removing them. Phase Il of the Program resulted in American and Polish companies' joint projects in the area of extension of the district heating network, elimination of local boiler houses by connecting their service areas to the municipal districtheating network and modernization of solid fuel-fired boiler houses.

On the basis of the experience gained in Phases I and II, an Implementation Plan for Elimination of Low Emissions was developed (see Chapter 5). The Plan is being gradually implemented. The chief investors are MPEC S.A., the district heat distribution utility, and the Kraków CHP Plant S.A., ECK S.A. As part of its new investment strategy, MPEC invests not only in connecting boiler houses to the municipal district heating network, but also in construction of gas-fired boiler houses. The conversion of boiler houses to gas is supported by the Gas Distribution Utility which involved its own funds and effort to connect new boiler houses to the gas network. The investors, both corporate and individual, can apply for financial support for environmentally-friendly projects to these organizations:

- Gminny Fundusz Ochrony Środowiska i Gospodarki Wodnej (GFOŚiGW) [Municipal Fund for Environmental Protection and Water Management];

- Wojewódzki Fundusz Ochrony Środowiska i Gospodarki Wodnej (WFOŚiGW) [Provincial Fund for Environmental Protection and Water Management];

- Narodowy Fundusz Ochrony Środowiska i Gospodarki Wodnej (NFOŚiGW) [National Fund for Environmental Protection and Water Management]; and

- EcoFund.

The funds can be disbursed in the form of subsidies or loans. There are formal limitations as to who can be granted a subsidy. The amount of funds available is limited, and they are usually awarded through a competition, in line with the following principles:

- $\quad$ subsidies from GFOŚiGW (in the amount of PLN 14 per $\mathrm{kg}$ of eliminated equivalent emission, not greater, however, than $35 \%$ of the capital costs) can be granted to municipal entities; 
field was added to the program managing the database, which describes boiler categories classified by the type of fuel, rated capacity, and, for solid fuel-fired boilers, the type of grate and air pollution control devices. By establishing this new category it is possible to connect the database to the modified version of the spreadsheet model.

The environmental legislative measures discussed above focussed interest on environmentally friendly fuels and technologies, and gradual elimination of low emission sources followed. In 1991 Cracow had:

- 1133 solid fuel-fired boilers and

-100,000 home stoves.

The elimination of boiler houses is progressing well. The main investors are MPEC S.A. and ECK S.A. That is why initially (in 1993-1995) the effort concentrated on connecting boiler houses to the municipal district heating network. Most boiler houses located close to the district heating network have already been hooked up. Since 1997, conversion of boiler houses to gas has prevailed. The table below shows the data for individual parts of Cracow.

\begin{tabular}{|l|r|r|r|r|r|r|}
\hline \multicolumn{7}{|c|}{ Table 4-1. Solid-fuel-fired Boilers in Cracow } \\
\hline \multicolumn{1}{|c|}{ Area } & 1991 & \multicolumn{1}{c|}{1993} & \multicolumn{1}{c|}{1995} & \multicolumn{1}{c|}{1997} & \multicolumn{1}{c|}{1998} & \multicolumn{1}{c|}{1999} \\
\hline Area 1- Old Town & 48 & 39 & 20 & 14 & $5^{*}$ & $2^{*}$ \\
\hline $\begin{array}{l}\text { Area 2 - 2nd ring } \\
\text { road }\end{array}$ & 365 & 304 & 220 & 127 & $92^{\circ}$ & $58^{*}$ \\
\hline $\begin{array}{l}\text { Area 3 - Outside } \\
\text { 2nd. ring road }\end{array}$ & 720 & 663 & 495 & 348 & $344^{*}$ & $277^{*}$ \\
\hline Total & 1,133 & 1,006 & 735 & 489 & $441^{*}$ & $337^{*}$ \\
\hline
\end{tabular}

${ }^{*}$ - planned

The elimination of home stoves is a slower process. It is estimated that in the years 1992-1998 some 28,000 coal-fired home stoves were eliminated, mostly through the installation of electric heating coils, less frequently through the installation of gas stoves. Due to the inconvenience associated with attending coal-fired stoves there is a great interest in the conversion. The elimination of stoves in the city center is limited by the inability to increase the power supply; the expansion of the power supply system is hindered by difficulties associated with finding locations for new transformer substations. Another obstacle to the elimination of coal stoves is the residents' and owners' lack of funds, which prevents the installation of a central heating system fired by gas.

\section{Capital Availability}

The political and economic changes that took place in Poland at the turn of the 1980s and 1990 s have led to an increased public interest in environmental protection on the one hand, 
subsidies from WFOŚiGW (up to $50 \%$ of the capital costs) can be granted to buildings owned by the municipality or by the State Treasury;

- preferential loans from WFOŚigW (up to $100 \%$ of the capital costs) can be granted only to those applicants who own the building;

- $\quad$ subsidies from EcoFund (up to $30 \%$ of the capital costs) are exclusively granted to owners of large facilities or investors applying jointly;

- $\quad$ subsidies or preferential loans from NFOSiGW are granted exclusively to owners of large facilities or investors applying jointly;

- investment funds offered by ECK S.A. are aimed at extension of the district heating network and construction of heat exchanger stations;

- $\quad$ investment funds offered by MPEC S.A. are aimed at extension of the district heating network and construction of heat exchanger stations and gas-fired boiler houses; and

- projects can be financed by companies like ESCO (Energy Service Company).

Those project initiators who have no funds can take advantage of the offer extended by MPEC S.A. which is described in the Boiler Conversion Program section of Chapter 5.

Owners of apartments willing to eliminate their coal-fired stoves can apply for subsidies from the WFOŚiGW. This subsidy, although covering only some portion of the costs incurred by residents, is a significant stimulus to converting home stoves to other heating systems. The subsidy has been granted since 1994 and involves some 3,000 stoves annually.

The possibility of obtaining external funds for building thermorenovation projects are limited. Such a possibility is offered by EcoFund, but only in the case of large buildings, and, to a very limited extent, by WFOŚiGW.

A new Act on Supporting Thermorenovation Initiatives is being prepared. The Act would make it possible to obtain credits for economically viable thermorenovation projects. Such a credit would be paid off by saving made on heating. An incentive for such projects would be a possibility of forgiving about $25 \%$ of the debt.

\section{Air Quality}

In the 1980's Cracow was particularly at risk because of air pollution. Residents suffered increased illness, and Cracow's unique buildings and monuments showed rapid degradation. The problem, particularly in the winter, was serious enough that some guidebooks warned tourists about possible health risks. Concentrations of pollutants regularly exceeded standards.

An air quality monitoring system was established in Cracow in 1991, a joint effort of the U.S. Environmental Protection Agency and the Provincial Environmental Protection Inspectorate in Cracow. Seven stationary stations and one mobile unit provide continuous monitoring of a number of pollutants, including $\mathrm{SO}_{2}, \mathrm{NO}, \mathrm{NO}_{2}, \mathrm{NO}_{\mathrm{x}}, \mathrm{CO}, \mathrm{O}_{3}$, and suspended particulates. Additionally, the content of heavy metals in suspended particulates and key weather parameters are measured. 
The graphs in figure 4-1 show the improvement in air quality in the center of Cracow, Rynek Główny. Winter levels of particulates now hover around the standard. The annual average concentrations of $\mathrm{SO}_{2}$ meet the standard, but the winter concentrations still exceed it. Similar results are seen in other areas of the city.

The gradual improvement in winter concentrations of these two pollutants clearly reflects the success of the Cracow LES Program. Of course, there are other sources of pollution, including industry and transportation as well as imported pollutants from other regions. Because the elimination of low emissions sources is proceeding so rapidly, it will be easier for Cracow to identify those other sources and direct resources to them. 

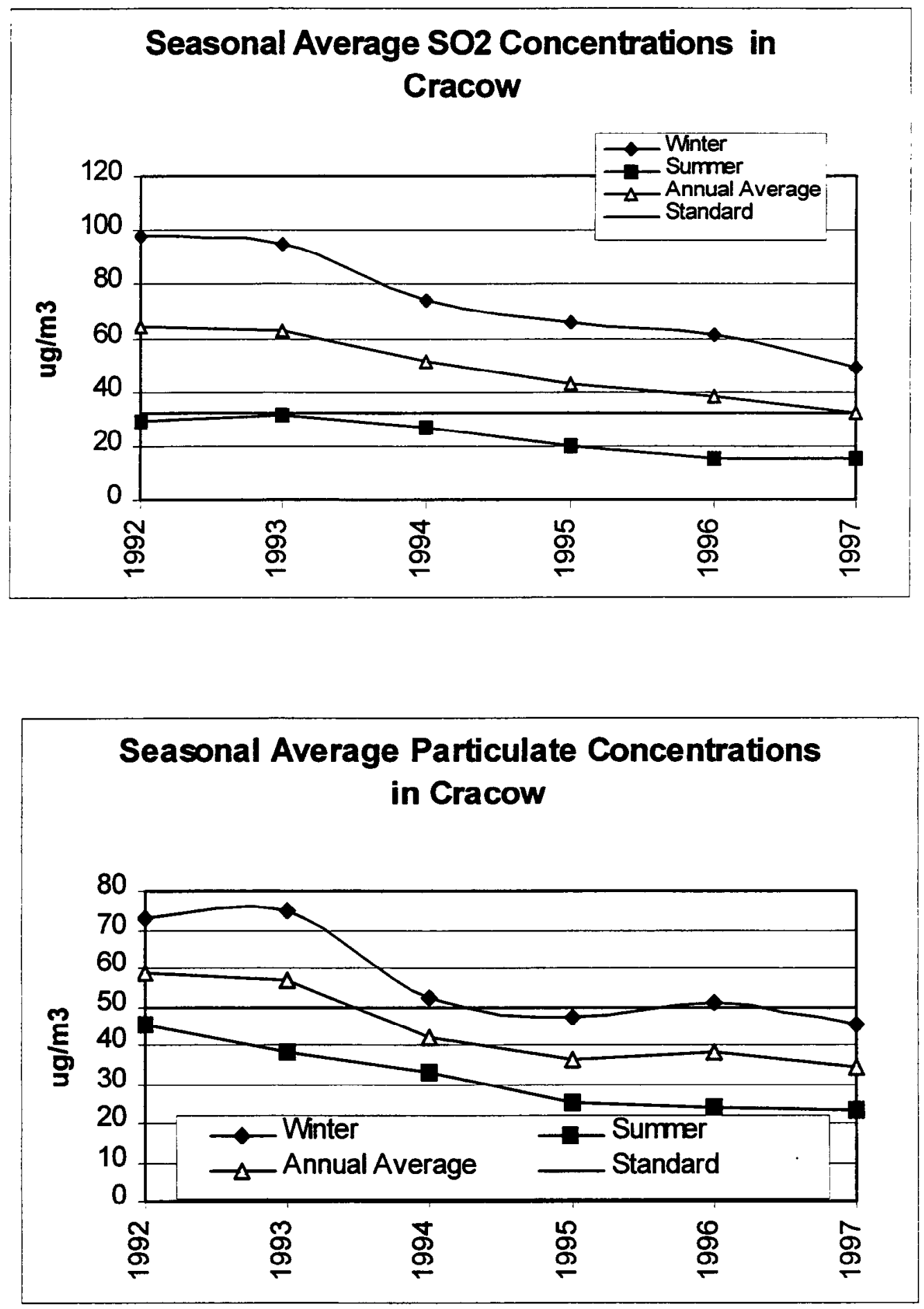

Figure 4-1. Air Quality in Cracow 


\section{Comprehensive Plan for Low Emission Sources}

Building on the work done in Phase I, BRK has developed a long term plan for low emission sources in Cracow. The City was divided into three areas, and plans developed for each. The areas are the center of Cracow called Old Town (Area 1), the area between the first and second ring roads (Area 2), and the area between the second ring road and the borders of the city (Area 3 ).

An updated version of the boilerhouse database developed during Phase I was used to evaluate the population of low emission sources in each area. The following table summarizes these for each area.

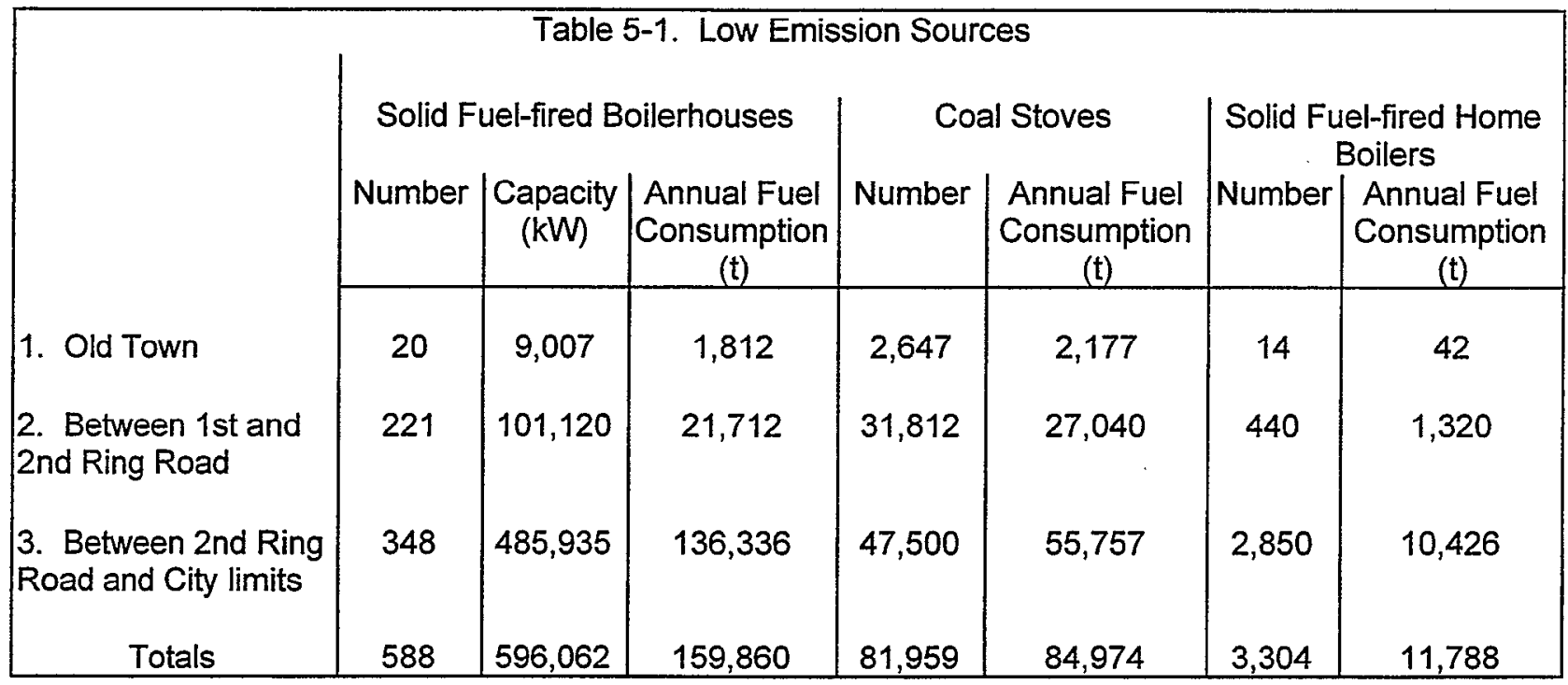

BRK looked at the utility infrastructure in each area, the costs of necessary improvements, and various conversion options to develop the optimum approach to eliminating the low sources. Results from Phase I studies were used to select options for further analysis. The spreadsheet that was refined in Phase I was used to evaluate viable options for each area of the city.

Old Town

In Old Town, the options selected for analysis are:

- conversion of coal or coke-fired boilers to gas;

- conversion of coal home boilers to gas; and

- conversion of coal stoves to stoves with electric inserts. 
Connection to the district heating network is not included because the network does not extend into the center of Cracow, and the age and historic character of the buildings in this area make it impractical to extend the network.

Based on the economic analysis provided by the spreadsheet, recommendations are to:

- convert $70 \%$ of the solid-fuel-fired boilers to gas; the remaining $30 \%$ would be unnecessary and can be eliminated;

- convert $100 \%$ of the small home coal boilers to gas; and

- convert $20 \%$ of the coal stoves to gas and $80 \%$ to electric heating.

To accommodate the increase in gas demand, some reconstruction of low-pressure pipelines will be needed. Conversion of coal stoves will need only connecting pipes and internal installations. Conversion of stoves to electricity will require construction of transformer stations and new distribution lines in some parts of Old Town. Based on past accomplishments, it is estimated that the low sources in Old Town can be eliminated by 2004. The total investment required is almost 6 million złotys (December 1996, $\$ 1=2.7$ złotys).

\section{Area 2}

In the area between the first and second ring roads, the options selected for further analysis are:

- conversion of solid-fuel-fired boilers to natural gas or connection to the district heating system;

- conversion of coal-fired home boilers to gas; and

- conversion of coal stoves to gas or to stoves with electric inserts.

Between the database update referenced above and March 31, 1997, 60 boilerhouses were eliminated from this area leaving 161 boilerhouses to be included in this analysis. Planning for this area also took into account the 1994 Cracow Development Plan, which defines land use and zoning requirements. The recommended approach to elimination of low emission sources in this area is to:

- connect 61 boilerhouses with a capacity of $30,290 \mathrm{~kW}$ to the district heating system;

- convert 100 boilerhouses with a capacity of $38,024 \mathrm{~kW}$ to gas;

- convert all of the small coal home boilers to gas; and

- convert $22 \%$ of the coal stoves to gas and $78 \%$ of them to use electric inserts.

Some expansion of the district network will be required, as well as construction of heating nodes in the connected buildings. In fact, some expansion is underway and planning has begun for a number of the district heat connections. As long as the necessary funding remains available, conversions can be completed by 2000 . Some gas and electric conversions can also be finished by 2000 , but most will take place between 2000 and 2009 
due to the large investment required to expand the utility networks. The electric system, in particular, will require significant expansion. The total investment for Area 2 is 85 million złotys (June 1997, $\$ 1=2.7$ złotys).

Area 3

In Area 3 , a large area extending from the $2^{\text {nd }}$ ring road to the city limits, options considered are:

- conversion of solid-fuel-fired boilers to natural gas or connection to the district heating system;

- modernization of stoker boilers;

- conversion of coal-fired home boilers to gas; and

- conversion of coal stoves to gas or to stoves with electric inserts.

The analysis took into consideration Cracow's land use planning, costs of utility network expansion, and capital and user costs. The recommended approach to eliminating low sources in this area is to:

- connect 182 boilerhouses (210.6 MW) to the district heating system;

- convert 164 boilerhouses (188 MW) to gas;

- modernize 2 boilerhouses (85.8 MW);

- convert all of the small home boilers to gas; and

- convert $40 \%$ of the home stoves to gas and $60 \%$ to electric storage heating.

Modernization of stoker boilers consists primarily of installing combustion controls and variable speed drives; modernization is one of the most cost-effective options. As for the other areas, the ratio of stove conversions to electric and gas is based on the current population of stoves in the area.

Recommendations to Municipal Authorities

The most significant barrier for low source elimination in Cracow is lack of funds. Many boilerhouse owners and residents do not have funds for conversions. Extensive utility expansions are required, particularly for electric conversions, and the utilities do not necessarily have the resources to accomplish this. There are also problems with siting new underground infrastructure facilities as well as time-consuming formal and legal procedures related to construction projects. In Old Town adequate sites for new transformer stations is a barrier to electric conversions. In Areas 2 and 3, most of the solid-fuel-fired boilers are small. Utilities are less interested in small facilities, and private investors have difficulty obtaining funding.

Obtaining funding for low source elimination can be a complicated undertaking. There are several possible sources, including environmental protection funds, foundations and assistance funds, and banks. These may offer outright grants up to a certain percent of 
the project's cost, or may offer loans at special rates. Qualification for the various sources depends on the owner's status and the type of project.

Recommendations to the municipal authorities include:

- declare that reduction of low emissions is a priority of the City, by adopting appropriate clauses in City Council resolutions and in the regulations of the Municipal and Voivodeship Environmental Protection and Water Management Funds;

- simplify and unify the procedures for obtaining funding from the Municipal and Voivode Funds;

- support conversion projects by providing information about potential funding and organizational assistance;

- encourage building owners to partner with utilities to obtain funding for conversions;

- in Old Town, permit the electric utility to construct transformer stations in buildings owned by the City;

- continue the subsidies for elimination of home stoves;

- as a temporary solution, restrict the availability of low-grade coal for use in home stoves; and

- as a complementary activity to low source elimination, support improvements in energy efficiency and building conservation projects.

\section{GIS}

One of the more innovative tasks in the Cracow Clean Fossil Fuels and Energy Efficiency Program is to link the database of boilerhouses and stoves with a Geographical Information System (GIS). The City has developed a GIS which includes district heat, gas and electric infrastructures as well as roads and buildings. Linking the database to the GIS allows planners to view emission densities from home heating systems, and to quickly evaluate impacts of the various conversion options under study in this Program.

Currently, the database has been converted to the format necessary for the GIS. BRK is preparing a report showing the capabilities of the system.

\section{Boiler Conversion Program}

The Cracow Clean Fossil Fuels and Energy Efficiency Program has been expanded to include direct participation in eliminating boilers by conversion or connection to the district heating system. Coal- and coke-fired boilers in the central part of Cracow contribute heavily to local air quality problems, and lack of financing has limited conversions. This activity will give priority to boilerhouses within the second ring road and nearby areas and boilerhouses located in buildings owned by the City. The Program may provide up to 50 percent of total project costs. 
On average, the Polish side will contribute at least $50 \%$ of the total project cost. Included in the U.S. share will be support work done by BRK and possibly BRK subcontractors, as well as equipment. The BRK support work includes public information efforts, negotiations with building owners, preparation of applications to funding sources, preparation of technical documentation, completion of required permit applications, the selection and purchase of equipment, and overall BRK project management costs.

BRK has publicly announced this program and solicited participation of building owners and third party investors. The primary criteria for selecting sites will be distance from the city center and feasibility of completing the work within the program schedule.

Individual building owners may directly participate in this program. They must, of course, provide their share of the funds either by direct investment or with support from the Gmina or Voivodship Environmental Funds. BRK will assist individual building owners with the fund application process.

It is likely that many building owners will choose to accept an arrangement like that currently offered by MPEC, the heat distribution utility. In this arrangement, MPEC will make common applications to funding sources for a group of buildings. MPEC will directly provide the balance of the investment (beyond U.S. share and funds from other sources). MPEC will do the conversion work at the site. The building owner will provide to MPEC free-of-charge use of the boilerhouse space and equipment in order to provide heat to the building. MPEC will own the newly installed equipment. Residents of the building will sign a heat supply contract with MPEC. One of the advantages of the MPEC arrangement is that it makes possible 15 to $30 \%$ support from the Ecofund. Ecofund will not directly support individual building owners.

ECKSA, which owns the cogeneration facility at Łeg, is also offering assistance in financing.

BRK will purchase the required conversion equipment. It is the intention of the program to use U.S. manufactured equipment where possible. The U.S. equipment must be certified as required in Poland, must have local service available, and must present no unreasonable cost burdens on the project. Equipment bids will be reviewed with the building owner or third party investor.

The boilerhouses will be converted after the 1999 heating season.

Status

To initiate this project, BRK provided information about the planned projects, the opportunities for building owners, and how to obtain additional information to the local press. BRK sent letters to the owners of approximately 150 boilerhouses in the central part of the city with more detailed information. These sites were targeted during development of the low source emissions plan described above. BRK has held several public meetings to discuss the program with boilerhouse owners. 
To date, 105 participants have been accepted. Almost half of the projects will be conversions to gas; the remainder will be connections to the district heating system. About 70 percent of the projects will be at least partially financed by MPEC. The following table summarizes the participating sites.

\begin{tabular}{|r|c|c|c|c|}
\hline \multicolumn{5}{|c|}{ Table 5-2. Sites Accepted for Conversion } \\
\hline & $\mathrm{kW}$ & $\%$ & $\begin{array}{c}\text { Number of } \\
\text { Boilerhouses }\end{array}$ & $\%$ \\
\hline Convert to gas & 19,470 & $48 \%$ & 51 & $49 \%$ \\
\hline Connect to district heat & 21,379 & $52 \%$ & $\underline{54}$ & $51 \%$ \\
\hline Total & 40,849 & & 105 & \\
\hline Financing & & & & \\
\hline MPEC & 29,020 & $71 \%$ & 72 & $69 \%$ \\
\hline ECKSA & 3,175 & $8 \%$ & 12 & $11 \%$ \\
\hline Owner & 8,654 & $21 \%$ & 21 & $20 \%$ \\
\hline Location & & & & \\
\hline Area 1 & 1,174 & $3 \%$ & 5 & $5 \%$ \\
\hline Area 2 & 8,134 & $20 \%$ & 33 & $31 \%$ \\
\hline Area 3 & 31,541 & $77 \%$ & 67 & $64 \%$ \\
\hline
\end{tabular}




\section{References}

1. Wojewódzki Inspectorat Ochrony Środowiska w Krakowie, Raport o środowiska w Województwie Krakowskim w 1996 Roku, Biblioteka Monitoringu Środowiska, Kraków, 1997.

2. Center for Co-operation with the Economies in Transition, Environmental Performance Reviews - Poland, Organization for Economic Co-operation and Development, Paris, 1995.

3. Kraków Clean Fossil Fuels and Energy Efficiency Program Phase I, T. Butcher and B. Pierce editors, Brookhaven National Laboratory Report BNL 52479, June 1995.

4. Plzeň Proceedings - Conference on Alternatives for Pollution Control from Coal-Fired Low Emission Sources, Plzeň Czech Republic, April 26-28, 1994, U.S. Department of Energy Report CONF-9404166.

5. Proceedings - Kraków Conference on Low Emission Sources, October 10-12, 1995, Cracow Poland. Brookhaven National Laboratory Report BNL-52472.

6. E.B. Woodruff and H. B. Lammers, Steam-Plant Operation, McGraw Hill, New York, 1950.

7. Steam Its Generation and Use, S.C. Stultz and J.B. Kitto editors, The Babcock and Wilcox Company, Ohio, 1992.

8. Gyorke, D. and T. Butcher. The selection of the American-Polish Joint Venture Projects for the Krakow program and the results of the efforts to date. Proceedings of the Krakow Conference on Low Emissions Sources, October 10-12, 1995, Brookhaven National Laboratory Report BNL - 52472, 1995.

9. Wysk S. Ronald and Surowka, J. Inertial particulate separator for reduction of LES emissions in Krakow. Plzen Proceedings - Conference on Alternatives for Pollution Control from Coal-Fired Low Emission Sources April 26-28, 1994, PIzen, Czech Republic, CONF9404166, 1994. 
